\title{
Foreign Aided: Why Democratization Brings Growth When Democracy Does Not
}

Hariri, Jacob Gerner

Published in:

British Journal of Political Science

DOI:

$10.1017 / \mathrm{S} 0007123413000276$

Publication date:

2015

Citation for published version (APA):

Hariri, J. G. (2015). Foreign Aided: Why Democratization Brings Growth When Democracy Does Not. British Journal of Political Science, 45(1), 53-71. https://doi.org/10.1017/S0007123413000276 


\section{British Journal of Political Science}

http://journals.cambridge.org/JPS

British

Journal of

Political

Additional services for British Journal of Political Science:

Science

Email alerts: $\underline{\text { Click here }}$

Subscriptions: $\underline{\text { Click here }}$

$\operatorname{Sin} x-100$

Commercial reprints: Click here

Terms of use : $\underline{\text { Click here }}$

CAMBRIDGE

\section{Foreign Aided: Why Democratization Brings Growth When Democracy Does Not}

Jacob Gerner Hariri

British Journal of Political Science / Volume 45 / Issue 01 / January 2015, pp 53 - 71

DOI: 10.1017/S0007123413000276, Published online: 09 October 2013

Link to this article: http://journals.cambridge.org/abstract_S0007123413000276

How to cite this article:

Jacob Gerner Hariri (2015). Foreign Aided: Why Democratization Brings Growth When Democracy

Does Not. British Journal of Political Science, 45, pp 53-71 doi:10.1017/S0007123413000276

Request Permissions : $\underline{\text { Click here }}$ 


\title{
Foreign Aided: Why Democratization Brings Growth When Democracy Does Not
}

\author{
JACOB GERNER HARIRI*
}

\begin{abstract}
There is an unresolved puzzle in research on the economics of democracy. While there is consensus that democracy is not generally associated with higher rates of economic growth, recent studies have found that democratization is followed by growth. But why should becoming a democracy bring growth if being one does not? This article shows that a substantial and immediate influx of foreign aid into new democracies accounts for the positive growth effect of democratization. The domestic regime characteristics of neither democracy nor democratization therefore seems to bring growth. The importance of aid in explaining the democratization-growth nexus underscores that democratizations do not occur in vacuum and cannot be fully understood from internal factors alone.
\end{abstract}

There is scholarly agreement that democracy is not associated with higher rates of economic growth than other regime forms. ${ }^{1}$ However a recent body of research has found that democratization is followed by a period of increased economic growth. ${ }^{2}$ This constitutes an unresolved puzzle, for why should becoming a democracy promote economic growth if being one does not? ${ }^{3}$ What factors distinguish young democracies from established democracies and can plausibly spur growth? This is all the more puzzling since many scholars expect democratic transitions to be associated with economic hardship. ${ }^{4}$

This article documents that across a wide range of specifications and controls, a substantial and immediate influx of aid into young democracies fully accounts for the positive growth effect of democratization. That is to say, democratization is associated

* Department of Political Science and Economics, Copenhagen University (email: jgh@ifs.ku.dk). I thank Robert Bates, Rune Bennike, Carl-Johan Dalgaard, Jørgen Elklit, Thraínn Eggertsson, Lene Hansen, Peter S. Jensen, Mogens Justesen, Robert Klemmensen Peter Kurrild-Klitgaard, Peter Nedergaard, David Dreyer Lassen, Jørgen Møller, Asmus Leth Olsen, Adam Przeworski, Shanker Satyanath, Svend-Erik Skaaning, Stefan Voigt, Asger Wingender, as well as the editor and three anonymous reviewers for very helpful comments on a previous version. Data replication sets and online appendices are available at http://dx.doi.org/doi: 10.1017/S0007123413000276.

1 See, for example, Dellepiane-Avelleneda 2010; Krieckhaus 2004; Przeworski et al. 2000; Sirowy and Inkeles 1990.

2 Giavazzi and Tabellini 2005; Papaioannou and Siourounis 2008; Persson 2005; Persson and Tabellini 2006; Rodrik and Wacziarg 2005. The democratization-growth nexus has proven robust to a variety of model specifications and controls (for example, Persson and Tabellini 2007).

3 Convergence is an obvious reason why democratization might enhance growth even if democracy does not: democratizing countries are relatively poor, so the effects of democratization could be confounded by the mechanics of economic catch-up. All democratization studies, however, control explicitly for the dynamics of convergence.

${ }^{4}$ For example, Przeworski et al. $(2000,188)$ argue that '[p]olitical upheavals [including regime transitions] divert resources and energies away from production and thus affect the contemporaneous growth of the economy'. Zakaria $(2003,99)$ points to 'a passing phase, the growing pains that young democracies must endure'. Similarly, Dahrendorf (1990, 138-9) argues that '[p]olitical transition leads to economic frustration, resulting in instability and unrest'. 
with growth, but this is caused by international redistribution rather than the domestic characteristics of political regime change in itself. This explanation resolves the puzzle, because it shows that the regime characteristics of neither young nor established democracies are, in themselves, growth promoting.

On a broader level, the article provides a complementary perspective on the importance of interstate linkages in political regime research. The existing literature on cross-country linkages and regime diffusion has focused on explaining if and when democratic transitions occur. ${ }^{5}$ The results in this article are complementary because they illustrate the importance of interstate linkages in understanding the causes and the consequences of democratization. Countries do not democratize in a vacuum, and whether democratization is the explanandum or (as here) the explanans, democratizations cannot be fully understood from internal factors alone.

On a methodological level, the results that follow illustrate why we should be cautious in treating reduced-form associations between political institutions and economic outcomes as causal, when it is often not specified how the political arrangement in question should affect the economy. Helpman and Dellepiane-Avellaneda also raised this point; they agree that one of the major shortcomings in the empirical institutionalist literature is that it 'still lacks a proper grasp of the channels through which institutions affect growth'. ${ }^{6}$ This article supplies one such channel for the case of institutional reform as democratization: aid. And since aid is not a characteristic of the political regime, identifying a link between democratization and growth substantively changes the conclusions that follow from reduced-form analyses. This illustrates why reduced-form associations should be treated with caution in empirical institutionalist research.

Lastly, the conclusions are of interest to the development community since they highlight an interesting circularity: much aid is conditioned on institutional reform based on the explicit presumption that the reform in question will help a country realize its growth potential. In the case of democratic reform, the results suggest that it is not the growth-promoting institutional reform in itself that brings growth, but rather the aid that comes with it.

To make these points, the article first re-establishes the positive association between democratization and growth using the difference-in-difference (DID)/fixed-effects specifications from the recent literature and shows that this positive association is driven by the early years of the democratic transition. These results are robust to a set of different specifications and, importantly, to a set of plausible mediating variables that has been considered in the literature. I then document a tight co-movement between aid and growth in the years following democratization. Aid, like growth, is significantly associated with democratization; and the inflow of aid, like the alleged growth effect, stops after about ten years. Finally, I show that across specifications and controls, the influx of aid to young democracies fully accounts for the positive association between democratization and growth.

The remainder of the article is organized as follows. The next section reviews the literature and takes a preliminary look at some of the channels that have been proposed to mediate the effect of democratization on growth. After describing the data and estimation approach, the main empirical results follow for the period 1960-2010. The penultimate section provides historical evidence from the period 1820-1959 along with robustness checks that use alternative measures of democracy and foreign aid. The final section concludes.

${ }^{5}$ See, for example, Elkink 2011; Gleditsch and Cederman, 2004; Gleditsch and Ward 2006; Starr 1991.

${ }^{6}$ Dellepiane-Avellaneda 2010, 196. See also Helpman 2004, 141. 
TWO BODIES OF REGIME RESEARCH AND A PUZZLE

There is scholarly agreement that democracy is not, in general, associated with higher rates of economic growth. For example, in their summary of the democracy-growth literature, Przeworski and Limongi found the evidence to be inconclusive: an equal number of studies reported in favor of democratic regimes and autocratic regimes, and a few found no significant differences across regime types. ${ }^{7}$ In a similar survey, Sirowy and Inkeles found 'a very mixed and confusing picture with regard to the effect of democracy on economic growth'. ${ }^{8}$ A decade later, Przeworski et al. concluded that 'the entire controversy seems to have been much ado about nothing' and, recently, Dellepiane-Avellaneda found that 'political regimes were not a key source of variation in observed growth rates'.?

In contrast to this early body of work, more recent studies have consistently found that becoming a democracy is positively associated with increased rates of economic growth. ${ }^{10}$ The five studies mentioned in the note use broadly similar specifications, and all confirm the positive association. Of particular interest here are the results from Rodrik and Wacziarg. These authors unpack the temporal dynamics of the democratization-growth nexus and demonstrate that the overall positive growth effect is driven by the early years of the regime transition. Not only is democratization growth promoting (while democracy is not), the overall effect of democratization is driven by the early years of becoming a democracy.

Methodologically, the democratization-growth literature rests on less stark assumptions for causal inference than the democracy-growth studies. ${ }^{11}$ While this is sometimes presented as a methodological argument in favor of the recent literature, ${ }^{12}$ one should bear in mind that, methodology aside, the research question is different: one literature inquires into the economics of regime form, the other into the economics of regime change.

If the conclusions from both literatures stand to reason, we are left with the puzzling result that economic growth accelerates while countries become democracies, and slows down when they are democracies. This naturally begs the question of what factor - that is plausibly associated with an immediate and short-lived growth effect - might distinguish

7 Przeworski and Limongi 1993.

8 Sirowy and Inkeles 1990, 137.

9 Dellepiane-Avellaneda 2012, 198; Przeworski et al. 2000, 178. In a careful analysis of the crosssectional literature, Krieckhaus (2004) found that the association between democracy and growth was sensitive to the choice of control variables as well as to the time period under consideration. Krieckhaus concluded that 'in the end, this article cannot resolve the question of whether democracy in fact influences economic growth' (2004, 653). See also Krieckhaus 2006.

${ }^{10}$ Giavazzi and Tabellini 2005; Papaioannou and Siourounis 2008; Persson 2005; Persson and Tabellini 2006; and Rodrik and Wacziarg 2005.

11 The estimated growth effect of democratization is in principle computed by subtracting the average annual growth change in countries that do not democratize from the average annual growth change in democratizing countries. This double difference (difference-in-difference) removes bias in comparisons between democratizers and non-democratizers that result from permanent differences between the two groups, as well as biases from comparisons over time in the group of democratizing countries that would result from time trends unrelated to democratization. The identifying assumption requires that democratizing countries, absent democratization, would on average have experienced the same growth rates as non-democratizing countries. For comparison, identification in the democracy-growth literature requires that there are no unobserved differences between democracies and non-democracies related to growth (one such difference could be, for example, culture).

12 For example, Giavazzi and Tabellini 2005, 1302. 

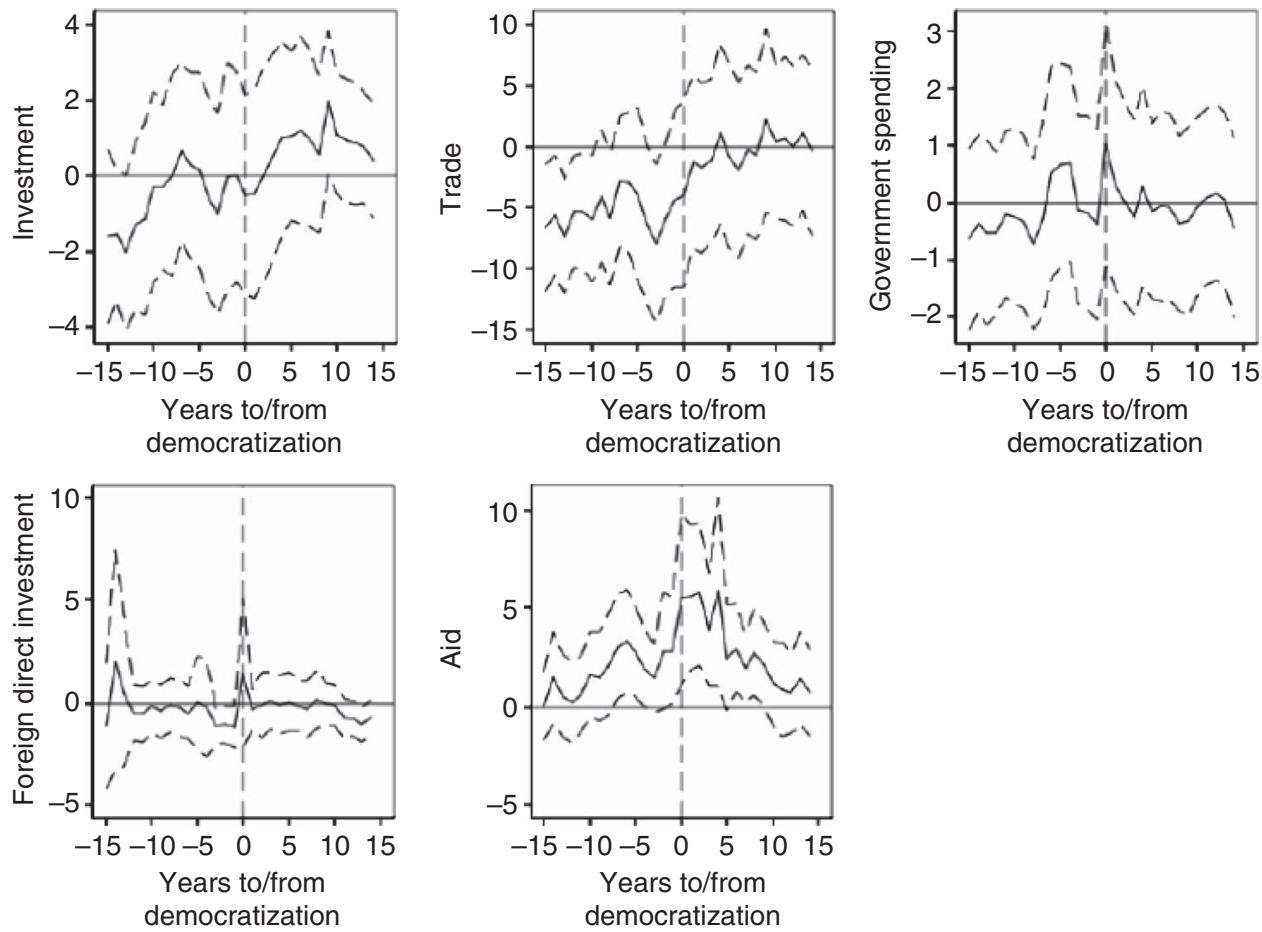

Fig. 1. Years around democratization

Note: The figure shows the coefficients on dummies for each of the years surrounding democratization. The analyses include country and year fixed effects. The dashed lines indicate the 95 per cent confidence interval. Sources: Marshall and Jaggers 2011, World Bank 2012.

democratizing countries from democracies? To provide a preliminary answer to this question, consider the channels proposed in the democratization-growth literature.

Papaioannou and Siourounis examine whether 'the significant effect of democratization [...] operates through capital accumulation or sound government or trade policies' and find a strong effect of democratization that is conditional on these channels. ${ }^{13}$ Giavazzi and Tabellini find 'some acceleration of growth (but not investment) at the time of democratization', and leave the channel unidentified. ${ }^{14}$ Persson and Tabellini ${ }^{15}$ also consider induced policy changes, focusing on government spending and subsequent economic liberalization. Conditional on economic liberalization, their estimate of the growth effect of democratization increases slightly. This finding suggests, again, that the association between democratization and growth does not run through subsequent economic liberalization.

Figure 1 shows the paths of the potential channels of influence (capital accumulation, government spending, trade flows, foreign direct investment and aid) for fifteen years

13 Papaioannou and Siourounis 2008, 1533.

14 Giavazzi and Tabellini 2005, 1319. The authors also find mixed effects on macroeconomic policies (lower government surplus, but higher inflation) as well as positive indications on the perception of good governance.

15 Persson and Tabellini (2006). 
on either side of the onset of democratization. ${ }^{16}$ This graphic illustrates whether, for example, investment or trade increases immediately after democratization, as one would expect if these factors were indeed the channels that link democratization and growth.

In the top left panel, there is some sign that investment rates pick up around the time of democratization, but the increase is never significantly different from zero (as can be seen from the lower dashed curve). In the top middle panel, trade flows also seem to increase, but the standard errors are far too large for them to be considered statistically significant. In the top right panel, there is some indication that government spending immediately spikes and gradually falls after democratization, but again the estimates are far from significant. Except for a random, but insignificant, spike in the fourteenth year preceeding democratization, foreign direct investment (bottom left panel) shows little variation around the time of democratization. The first four panels in Figure 1, like the recent literature, thus leave unidentified the factors that mediate the association between democratization and growth.

Yet arguably, there is nothing about reasonably free elections in themselves that affects national income. So if the euphoria of political emancipation is not in itself sufficient to raise productivity and national income, we should be able to uncover the channels of influence. The bottom middle panel shows that aid inflows visibly spike immediately upon democratization. The average democratizing country receives an immediate injection of aid of about 6 per cent of gross national income (GNI) in the first five years after democratization, and aid levels remain significantly elevated for about a decade. In contrast to the other candidate variables, the association between aid and democratization is significant during most of the post-democratization period - particularly in the immediate post-transition years, which Rodrik and Wacziarg found to be driving the positive association between democratization and growth. Even if preliminary and univariate, the evidence in Figure 1 suggests that analyses of the democratization-growth nexus should take the influx of aid into account. Before doing so, I briefly describe the operationalization of democratization, the data and the estimation approach used.

\section{DATA, OPERATIONALIZATION AND ESTIMATION APPROACH}

In keeping with the recent democratization-growth literature, the analyses that follow use the Polity IV measure of democracy (the 21-point scaled variable polity2). While this measure of democracy is standard in the empirical literature, it has been the subject of some debate. ${ }^{17}$

\footnotetext{
16 The variables are the following series from the World Development Indicators (World Bank 2012): gross fixed capital formation (per cent of gross domestic product, GDP), trade (per cent of GDP), general government final consumption expenditure (per cent of GDP), foreign direct investment, net inflows (per cent of GDP) and official development assistance (per cent of GNI).

17 Since Robert Dahl's seminal 1971 contribution, Polyarchy: Participation and Opposition, the literature on measuring democracy has come close to a consensus that, as proposed by Dahl, the constitutive attributes of democracy are participation and contestation. Contestation is the right of at least some of the population to 'contest the conduct of the government', and participation is the proportion of the population that is entitled to do so (Dahl 1971, 1-8). For example, Huntington 1991, 7; Lijphart 1999, 48-9; Munck and Verkuilen 2002, 9; and Vanhanen 2000, 253 all explicitly build upon Dahl's two-dimensional conceptualization of democracy. The conceptualization of democracy in Polity IV has been criticized for ignoring the second dimension, participation. In the words of Munck and Verkuilen $(2002,11)$, however, conditional on contestation, 'universal suffrage can be taken for granted in the post-1945 period'. See also Przeworski et al. $(2000,34)$ for a similar argument. The core analyses examine the post-1945 period, but are not completely insulated from this critique, given that some of the robustness checks extend as far back as 1820. There, the omission of the participation
} 
The core findings are therefore reproduced using the so-called ACLP indicator, which was originally constructed by Przeworski et al. and recently updated by Cheibub, Gandhi and Vreeland. $^{18}$

Polity IV offers a tripartite distinction between autocracy (polity score below 1), partial democracy (polity score 1-6) and full democracy (polity score 7-10). ${ }^{19}$ Following this classification, I refer to democratization as the event of becoming a (partial or full) democracy if a country was an autocracy in the previous year. This is the operationalization used in the democratization-growth literature. ${ }^{20}$ To keep the results comparable, it is crucial to use the same. This yields a total of sixty-nine democratizations in the period under consideration $(1960-2010) .^{21}$ A full list is available in the online appendix.

With this basic operationalization, I first defined a single democratization dummy that takes the value 1 in the year a country passes the threshold, and stays at 1 for all years in which the country remains a partial or full democracy. This operationalization follows, for example, the work of Persson and Tabellini and Giavazzi and Tabellini. ${ }^{22}$ Secondly, I carved the event of democratization into three consequtive phases, each of which is represented by a dummy variable. Phases 1 and 2 last five years each, while Phase 3 measures subsequent years (if the country does not revert back to autocracy). This approach is similar to that of Rodrik and Wacziarg. ${ }^{23}$

With these variables, I estimate a fixed-effects DID model. The baseline estimating equation is:

$$
g_{i, t}=\alpha_{i}+\phi D_{i, t}+\beta y_{i, t-1}+\gamma X_{i, t}+\mu_{t}+\varepsilon_{i, t},
$$

where $g_{i, t}$ is annual growth in per capita GDP in country $i$ in year $t . D_{i, t}$ is the binary democratization indicator, which captures all years after a country's polity score becomes strictly positive. The coefficient of primary interest is $\phi$, which measures the correlation between economic growth and democratization. As described above, to examine the temporal dynamics, the event of democratization was carved into three consecutive phases, each of which is represented by a dummy variable. When estimating this model,

(F'note continued)

dimension is potentially problematic. Still, the Polity IV measure is used to retain consistency with the research on democratization and growth, to which this study is most directly related.

${ }^{18}$ Cheibub, Gandhi, and Vreeland (2009); Przeworski et al. (2000).

${ }^{19}$ Marshall and Jaggers 2011, 35.

${ }^{20}$ For example, Giavazzi and Tabellini 2005, 300; Persson and Tabellini 2006, 319.

${ }^{21}$ Following Giavazzi and Tabellini $(2005,1304)$ and Persson and Tabellini (2006, note 1), the following specific coding rules were used. (1) A minimum of five years of data after the start of democratization is required to include a country as an instance of democratization. This rules out Gabon, which democratized in 2009 according to the operationalization used here. (2) At least one year of data is required before the country democratizes to include it as an instance of democratization. This rules out Ukraine and others that are coded as democratic throughout and belong to the control group. (3) At least five uninterrupted years of democratization are required before they are counted as such. Shorter democratic reversals (polity2 falling below one for four years or less) are counted as 'autocratic interim', and all specifications include autocratic and democratic interim dummies. The autocratic dummy variable takes the value 1 for Thailand in 1991, Albania in 1996 and Peru in 1992, among a few others.

${ }^{22}$ Giavazzi and Tabellini 2005; Persson and Tabellini 2006.

${ }^{23}$ Rodrik and Wacziarg 2005. When estimating this model, following Rodrik and Wacziarg, controls for autocratization (defined as the mirror image of democratization, and lasting up to ten years) and state failure as coded by Polity IV are included. 
the democratization indicator, $D_{i, t}$ in Equation 1 is simply replaced by the three dummies (Phase $1_{i, t}$, Phase $2_{i, t}$ and Phase $3_{i, t}$ as defined earlier). Lagged per capita income, $y_{i, t-1}$, is included to allow for economic convergence. $X_{i, t}$ is a vector of control variables. In all specifications, the control vector includes a dummy for the five years that precede democratization in order to account for the possibility that democratization occurs in response to changed economic performance. It also detects systematic 'pre-treatment' differences between democratizing and non-democratizing countries (all conclusions also hold without controlling for pre-democratization years). Regional dummies interacted with time for Africa, Latin America, post-communist countries and oil-producing countries are also included as controls. ${ }^{24}$ All models are run twice: first in reduced form (the potential channels - capital accumulation, government spending, trade and economic liberalization - are not controlled for) and secondly, including these channels as part of $X_{i, t}$. The three remaining terms are unobserved effects. Country-specific, time-invariant characteristics, $\alpha_{i}$, are controlled for using the fixed-effects specification. The time-varying unobserved effects, $\mu_{t}$, are controlled for by including a full set of year dummies for 1961-2010. $\varepsilon_{i, t}$ is the idiosyncratic error term (unobserved effects that vary across countries and over time).

In some specifications, Equation 1 is estimated as an autoregressive distributed lag (ADL) model, including two lags of the dependent variable $\left(g_{i, t-1}\right.$ and $\left.g_{i, t-2}\right)$ in addition to the lagged income per capita. This was done to address the issue of serial correlation, which attenuates standard errors and can be particularly problematic for the DID estimator. ${ }^{25}$ The ADL specifications also include a two-year lag as well as a contemporaneous and lagged difference of all economic controls. ${ }^{26}$ This specification follows Papaioannou and Siourounis. ${ }^{27}$ In all models, standard errors are robustly clustered at the country level in order to minimize arbitrary heteroskedasticity and serial correlation. $^{28}$

The core analyses employ a panel data set of 124 countries in the period 1960-2010, with a total of 4,402 observations. Economic data for the period 1960-2010 are from the World Bank, while the historical growth data (1820-1959) used for robustness checks are from Maddison. ${ }^{29}$ The main specifications code democratizations from the Polity IV data set are as explained above, but robustness checks were conducted using the dichotomous ACLP indicator. Following the voluminous aid-growth literature, the main measure of aid is net official development assistance (ODA) normalized by income (net ODA as per cent of GNI). ${ }^{30}$ Robustness checks were conducted using David

\footnotetext{
${ }^{24}$ It is well known that democratizations tend to cluster geographically and temporally (for example, Latin America in the 1980s and post-communist countries in the 1990s). If such clustering coincides with growth trends that are unrelated to democratic reform, this would bias the estimates. All conclusions are upheld if post-communist countries are removed altogether, and without regional dummies. Also included also is a 'US friend' dummy, which is standard in the aid-growth literature. It is assigned a value of 1 for Egypt and Israel and 0 otherwise.

${ }_{25}$ Bertrand et al. 2004.

${ }^{26}$ More specifically, Equation 1 was also estimated as: $g_{i, t}=\alpha_{i}+\phi D e m o c_{i, t}+\beta y_{i, t-1}+\pi g_{i, t-1}+F(L) X_{i, t}+$ $C(L) \Delta X_{i, t-1}+\mu_{t}+\varepsilon_{i, t}$.

${ }^{27}$ Papaioannou and Siourounis 2008.

${ }^{28}$ In all models, classical and robust standard errors are identical to at least the fourth decimal. This is reassuring, given the warning in King and Roberts (2012) that a difference can be a sign of model misspecification.

29 World Bank 2012; Maddison 2010.

${ }^{30}$ For example Dalgaard, Hansen, and Tarp 2004
} 
TABLE 1 Democratization and Economic Growth

\begin{tabular}{|c|c|c|c|c|c|c|}
\hline & \multicolumn{3}{|c|}{ Reduced-form associations } & \multicolumn{3}{|c|}{ Controlling for channels } \\
\hline & (1) & (2) & (3) & (4) & (5) & (6) \\
\hline Democratization & $\begin{array}{c}0.80^{*} \\
(0.43)\end{array}$ & $\begin{array}{l}0.71 * * \\
(0.34)\end{array}$ & & $\begin{array}{l}0.82 * * \\
(0.39)\end{array}$ & $\begin{array}{l}0.82^{* *} \\
(0.37)\end{array}$ & \\
\hline Democratization Phase 1 & & & $\begin{array}{c}0.63 \\
(0.55)\end{array}$ & & & $\begin{array}{l}1.28 * * * \\
(0.50)\end{array}$ \\
\hline Democratization Phase 2 & & & $\begin{array}{l}1.04^{* *} \\
(0.48)\end{array}$ & & & $\begin{array}{l}0.98^{* *} \\
(0.43)\end{array}$ \\
\hline Democratization Phase 3 & & & $\begin{array}{c}0.18 \\
(0.51)\end{array}$ & & & $\begin{array}{c}-0.25 \\
(0.50)\end{array}$ \\
\hline Pre-Democratization & $\begin{array}{c}0.23 \\
(0.61)\end{array}$ & $\begin{array}{c}0.20 \\
(0.48)\end{array}$ & $\begin{array}{c}0.32 \\
(0.61)\end{array}$ & $\begin{array}{c}0.49 \\
(0.42)\end{array}$ & $\begin{array}{c}0.43 \\
(0.36)\end{array}$ & $\begin{array}{c}0.52 \\
(0.42)\end{array}$ \\
\hline Other regime change & No & No & Yes & No & No & Yes \\
\hline Liberalization & No & No & No & Yes & Yes & Yes \\
\hline Economic controls & No & No & No & Yes & Yes & Yes \\
\hline Observations & 4,402 & 4,185 & 4,384 & 3,508 & 3,275 & 3,508 \\
\hline Countries & 124 & 123 & 123 & 118 & 115 & 118 \\
\hline $\mathrm{R}^{2}$ & 0.11 & 0.15 & 0.14 & 0.20 & 0.21 & 0.20 \\
\hline
\end{tabular}

Note: The dependent variable is GDP per capita growth. All models contain country and year fixed effects, lagged income per capita, indicators for short regime interims and time-interacted regional dummies for Africa, post-communist countries, Latin America and oil-exporting countries. Column 2 includes two lags of the dependent variable. Column 3 controls for autocratization and state failure. Columns 4-6 control for investment, trade, government spending and economic liberalization. Column 5 contains a contemporaneous lag and two lags of the difference of economic controls. Robust standard errors are clustered by country in parentheses. ${ }^{* *} \mathrm{p}<0.01,{ }^{* *} \mathrm{p}<0.05,{ }^{*} \mathrm{p}<0.1$. Sources: Marshall and Jaggers (2011), World Bank (2012), Giavazzi and Tabellini (2005).

Roodman's Net Aid Transfers (NAT) dataset. ${ }^{31}$ The NAT measure differs from the ODA in that it excludes cancellations of foreign debt as an aid transfer and nets out loan interest payments. These analyses use the dollar amount of aid (specifically, the natural $\log$ thereof to reduce the weight of outliers) to address the concern that regressing growth on aid normalized by income creates problems of reverse causality. ${ }^{32}$ It is reassuring, therefore, that the results are very similar whether aid is normalized or not. The sample is restricted to country-years for which aid data are available even when aid is not included in the analyses, so that the sample stays constant before and after controlling for aid.

\section{RESULTS: DEMOCRATIZATION AND ECONOMIC GROWTH}

Estimates of Equation 1 are reported in Table 1. Column 1 shows the coefficient from the simple DID workhorse model that is commonly used in the literature. Column 2 estimates the ADL version of Equation 1 as described above, and Column 3 replaces the single democratization indicator by the three phase dummies. Columns $4-6$ are identical to the

31 Roodman 2008.

${ }^{32}$ See, for example, Wright and Winters 2010. 
first three columns, but add controls for the set of proposed mediating variables. Rows 11-13 show which controls are included in the individual models.

The coefficient in Column 1 shows the association between democratization and growth (and is directly comparable to the coefficient in Persson and Tabellini (2006) Table 1, Column 1). I find a significant and sizeable annual growth increase of 0.80 per cent, which is substantial. ${ }^{33}$ For comparison, the Persson and Tabellini study found 0.75 at a similar level of significance. The pre-democratization indicator has an insignificant coefficient of 0.23 , which suggests that the regime transition does not occur in response to changed economic performance in the five years preceeding it. As mentioned above, the DID estimator rests on the strong assumption that in the absence of treatment, the average outcomes for treated and controls would have followed parallel paths. In all models, the pre-democratization dummy is consistently insignificant, which shows that before the treatment, treated and controls did in fact follow parallel paths. Prima facie, this corroborates the identifying assumption of parallel trends absent treatment. The coefficient on lagged GDP per capita is significantly negative (not shown), documenting a conditional convergence effect. What matters here is that the estimated growth effect of democratization does not simply capture convergence.

Column 2 is identical to Column 1, except that it introduces richer time dynamics to allow for persistence in economic growth rates. The specification here includes two lags of the dependent variable, which makes the specification similar to Papaioannou and Siourounis, Table 2, Column 5. Allowing for growth inertia does not change the estimated growth effect of democratization, even if the estimate of 0.71 is somewhat smaller than that found in Papaioannou and Siourounis, who report 1.09 with identical levels of significance.

The model in Column 3 adopts the approach in Rodrik and Wacziarg to uncover the temporal dynamics of the democratization-growth nexus. Instead of estimating the effect of democratization en bloc, the event of becoming a democracy has been divided into three phases. Column 3 documents a hill-shaped relationship similar to the result in Rodrik and Wacziarg, Table 1, Columns 2-4: the positive association between democratization and growth is transitory and dies off after about ten years.

Columns 4-6 control for factors that could reasonably mediate a short-run association between democratization and growth, and have been proposed in the literature: investment, government consumption, trade and subsequent economic liberalization. ${ }^{34}$ The overall conclusion is easily summarized: conditional on this set of controls, we still see an immediate, sizeable and significant association between democratization and growth. I interpret this as evidence that the growth effect of democracy is not mediated

\footnotetext{
${ }^{33}$ To get a sense of the magnitude, consider the example of Spain, which democratized in 1976 with a real per capita income of 8,606 (constant USD). In 2010, per capita income was 15,462 corresponding to an average annual growth rate of 1.7 per cent. Had Spain not democratized, annual growth would (assuming that the average fits Spain) have been lower by 0.80 per cent. In 2010, Spain would then have had an income of 11,822, not much higher than contemporary income in Trinidad.

${ }^{34}$ Here, following the literature, a country is considered illiberal if (1) average tariffs exceed 40 per cent, (2) non-tariff barriers cover more than 40 per cent of imports, (3) the country has a socialist economic system, (4) the black market exchange rate premium exceeds 20 per cent and (5) most exports are controlled by a state monopoly. The first year in which none of these conditions apply is considered the first year of liberalization. Giavazzi and Tabellini (2005, 1315 and Appendix C) report that democratization increases the probability of economic liberalization by 32 per cent.
} 
TABLE 2 Democratization and Foreign Aid Receipts

\begin{tabular}{|c|c|c|c|c|c|c|}
\hline & \multicolumn{3}{|c|}{ Reduced-form associations } & \multicolumn{3}{|c|}{ Controlling for channels } \\
\hline & (1) & (2) & (3) & (4) & (5) & (6) \\
\hline Democratization & $\begin{array}{l}1.22^{* *} \\
(0.50)\end{array}$ & $\begin{array}{l}0.96^{* *} \\
(0.42)\end{array}$ & & $\begin{array}{l}1.11^{* *} \\
(0.49)\end{array}$ & $\begin{array}{l}1.04 * * \\
(0.49)\end{array}$ & \\
\hline Democratization Phase 1 & & & $\begin{array}{l}1.93^{* *} \\
(0.78)\end{array}$ & & & $\begin{array}{l}1.70^{*} \\
(0.69)\end{array}$ \\
\hline Democratization Phase 2 & & & $\begin{array}{c}1.29^{*} \\
(0.72)\end{array}$ & & & $\begin{array}{c}0.58 \\
(0.46)\end{array}$ \\
\hline Democratization Phase 3 & & & $\begin{array}{c}0.25 \\
(0.39)\end{array}$ & & & $\begin{array}{c}0.50 \\
(0.44)\end{array}$ \\
\hline Pre-Democratization & $\begin{array}{c}0.57 \\
(0.35)\end{array}$ & $\begin{array}{c}0.53 \\
(0.40)\end{array}$ & $\begin{array}{c}0.59 \\
(0.36)\end{array}$ & $\begin{array}{c}0.61 \\
(0.44)\end{array}$ & $\begin{array}{c}0.72 * \\
(0.42)\end{array}$ & $\begin{array}{c}0.62 \\
(0.44)\end{array}$ \\
\hline Other regime change & No & No & Yes & No & No & Yes \\
\hline Liberalization & No & No & No & Yes & Yes & Yes \\
\hline Economic controls & No & No & No & Yes & Yes & Yes \\
\hline Observations & 4,386 & 4,171 & 4,368 & 3,496 & 3,265 & 3,496 \\
\hline Countries & 123 & 123 & 122 & 117 & 115 & 117 \\
\hline $\mathrm{R}^{2}$ & 0.56 & 0.57 & 0.57 & 0.53 & 0.50 & 0.53 \\
\hline
\end{tabular}

Note: The dependent variable is $O D A$ in percent of GNI. All models contain country and year fixed effects, lagged income per capita, lagged aid, indicators for short regime interims and time-interacted regional dummies for Africa, post-Communist countries, Latin America and oil-exporting countries. Column 2 includes two lags of the dependent variable. Column 3 controls for autocratization and state failure. Columns 4-6 control for investment, trade, government spending and economic liberalization. Column 5 contains a contemporaneous lag and two lags of the difference of economic controls. Robust standard errors are clustered by country in parentheses. ${ }^{* * *} \mathrm{p}<0.01,{ }^{* *} \mathrm{p}<0.05,{ }^{*} \mathrm{p}<0.1$. Sources: Marshall and Jaggers (2011), World Bank (2012), Giavazzi and Tabellini (2005).

through these channels. The coefficients in Column 6 imply that after ten years, the average democratizing country is richer by 11.9 per cent in real per capita GDP compared to before democratic reform. Interestingly, Column 6 shows that adding these controls attenuates the Phase 2 coefficient. This is intuitive. First, it seems natural to assume that it takes a few years after a major reform for investment rates and trade flows to increase. Secondly, Giavazzi and Tabellini demonstrate that the average time lag between democratization and subsequent economic liberalization is four years. Both observations are consistent with the attenuation found in the second phase of the democratic transition. More surprisingly, Column 6 also shows that the Phase 1 coefficient increases substantially conditional on the set of economic controls. So if it is not political emancipation in and of itself or the set of economic controls traditionally considered in the literature, what is it about democratization that stimulates the economy within the first five or ten years?

I make the claim that international redistribution in the form of foreign aid to new democracies shows up as growth in the short run in two steps. First, I redo Table 1 using foreign aid as the dependent variable to illustrate how foreign aid and growth generally move in tandem during democratizations. Secondly, I repeat Table 1 again, this time controlling for inflows of foreign aid to see if the growth-accelerating effect of democratization is robust to this channel. It is not. 


\section{DEMOCRATIZATION AND INTERNATIONAL REDISTRIBUTION}

Figure 1 indicated that donor governments' aid allocation rules are responsive to regime changes. The average democratization was accompanied by an immediate spike in aid inflows of about 6 per cent of GNI; young democracies are donor darlings. This confirms the notion that foreign aid flows respond to donor interests and politics. ${ }^{35}$ Moreover, while foreign aid targeted specifically at democracy-related programs remains relatively modest, it is increasingly common to condition budget support (in the form of grants or loans) on democratic performance. ${ }^{36}$ Table 2 confirms the association between aid and democratization.

Table 2 is structured the same way as Table 1 . The first three columns redo the core specifications in the democratization-growth literature, but this time with aid inflows in per cent of GNI as the dependent variable. The last three columns include the same controls as in Table 1.

The table reveals a similarity in the way aid and growth respond to democratic reform: aid, like growth, is substantively and significantly associated with the event of becoming a democracy. And aid, like growth, exhibits a hill-shaped relationship to democratic reform. In both cases, the correlations are particularly strong and particularly significant in the early years of democratization, disappear after around ten years and are robust to the inclusion of economic controls. In short, aid and growth move in tandem in the early years of young democracies.

We proceed to examine if there is an independent association between democratization and growth once aid is controlled for. To do so, the analyses from Table 1 are repeated, this time including the inflow of foreign aid in per cent of GNI as a control variable.

In all six specifications, controlling for aid strongly attenuates the coefficient on democratization, and in all specifications the coefficients turn insignificant. In all specifications, foreign aid (lagged one period) is very significantly associated with growth. The coefficient estimates for aid range from 0.08 to 0.14 , which is slightly smaller than existing studies. Most studies report coefficients around $0.15 .{ }^{37}$ When democratic reform is considered en bloc, as in Columns 1-2 and 4-5, the coefficient on democratization is literally cut in half. Recall that in Table 1, the first two columns showed a significant and substantial association between democratization and growth of 0.80 and 0.71 per cent, respectively. In the two first columns in Table 3, which hold the exact same specifications except that aid is included, the corresponding estimates are 0.41 and 0.35 , respectively. Columns 3 and 6 show that the estimated association is attenuated most strongly in the early years of the transition. Thus conditional on aid, the estimated coefficient on the first five years of democracy drops from 0.64 to 0.21 and 1.28 to 0.68 in Columns 3 and 6 , respectively. This is unsurprising. Given that the aid inflow was strongest in the early years of democratization, we should expect to see the largest reduction of the democratizationgrowth association in the same years. Overall, Table 3 shows that, conditional on aid, there are few signs of a positive growth effect of democratization. The consistency of this

\footnotetext{
${ }^{35}$ To take one example, Drury, Olson, and Van Belle (2005) showed that not only does US development assistance respond to US strategic interests, but the same applies to US disaster assistance, which is commonly seen as the least politicized component of US aid.

36 See, for example, Carothers 1999; Cornell 2012; Knack 2004; Wright and Winters 2010.

37 For example, Hansen and Tarp 2000; Werker, Ahmed, and Cohen 2009.
} 
TA B LE 3 Democratization, Aid and Growth

\begin{tabular}{|c|c|c|c|c|c|c|}
\hline & \multicolumn{3}{|c|}{ Reduced-form associations } & \multicolumn{3}{|c|}{ Controlling for channels } \\
\hline & (1) & (2) & (3) & (4) & $(5)$ & (6) \\
\hline Democratization & $\begin{array}{c}0.41 \\
(0.41)\end{array}$ & $\begin{array}{c}0.35 \\
(0.33)\end{array}$ & & $\begin{array}{c}0.34 \\
(0.40)\end{array}$ & $\begin{array}{c}0.43 \\
(0.38)\end{array}$ & \\
\hline Democratization Phase 1 & & & $\begin{array}{c}0.20 \\
(0.55)\end{array}$ & & & $\begin{array}{c}0.68 \\
(0.49)\end{array}$ \\
\hline Democratization Phase 2 & & & $\begin{array}{c}0.60 \\
(0.49)\end{array}$ & & & $\begin{array}{c}0.59 \\
(0.46)\end{array}$ \\
\hline Democratization Phase 3 & & & $\begin{array}{c}0.00 \\
(0.49)\end{array}$ & & & $\begin{array}{c}-0.57 \\
(0.52)\end{array}$ \\
\hline Pre-Democratization & $\begin{array}{c}0.01 \\
(0.60)\end{array}$ & $\begin{array}{c}0.00 \\
(0.47)\end{array}$ & $\begin{array}{c}0.10 \\
(0.60)\end{array}$ & $\begin{array}{c}0.23 \\
(0.44)\end{array}$ & $\begin{array}{c}0.21 \\
(0.38)\end{array}$ & $\begin{array}{c}0.26 \\
(0.43)\end{array}$ \\
\hline Lag foreign aid & $\begin{array}{l}0.09^{* * *} \\
(0.03)\end{array}$ & $\begin{array}{l}0.10^{* * * *} \\
(0.04)\end{array}$ & $\begin{array}{l}0.08^{* * *} \\
(0.03)\end{array}$ & $\begin{array}{l}0.12^{* * *} \\
(0.04)\end{array}$ & $\begin{array}{l}0.14^{* * * *} \\
(0.04)\end{array}$ & $\begin{array}{l}0.12^{* * *} \\
(0.04)\end{array}$ \\
\hline Other regime change & No & No & Yes & No & No & Yes \\
\hline Liberalization & No & No & No & Yes & Yes & Yes \\
\hline Economic controls & No & No & No & Yes & Yes & Yes \\
\hline $\begin{array}{l}\text { Observations } \\
\text { Countries }\end{array}$ & 4,402 & 4,185 & $\begin{array}{c}4,384 \\
123\end{array}$ & $\begin{array}{c}3,508 \\
118\end{array}$ & 3,275 & 3,508 \\
\hline $\begin{array}{l}\text { Countries } \\
\mathrm{R}^{2}\end{array}$ & $\begin{array}{l}124 \\
0.12\end{array}$ & $\begin{array}{l}123 \\
0.16\end{array}$ & $\begin{array}{l}123 \\
0.15\end{array}$ & $\begin{array}{l}118 \\
0.22\end{array}$ & $\begin{array}{l}115 \\
0.22\end{array}$ & $\begin{array}{l}118 \\
0.22\end{array}$ \\
\hline
\end{tabular}

Note: The dependent variable is GDP per capita growth. All models contain country and year fixed effects, lagged income per capita, indicators for short regime interims and time-interacted regional dummies for Africa, post-Communist countries, Latin America and oil-exporting countries. Column 2 includes two lags of the dependent variable. Column 3 controls for autocratization and state failure. Columns 4-6 control for investment, trade, government spending and economic liberalization. Column 5 contains a contemporaneous lag and two lags of the difference of economic controls. Robust standard errors are clustered by country in parentheses. $* * * p<0.01, * * p<0.05$, $* p<0.1$. Sources: Marshall and Jaggers (2011), World Bank (2012), Giavazzi and Tabellini (2005).

conclusion across specifications and controls is remarkable, particularly given the sensitivity of the democracy-growth association to the choice of controls. ${ }^{38}$

Figure 2 illustrates the article's key result. The solid curve demonstrates that aid increases around the time of democratization and tapers off after about ten years, resulting in the hill-shaped association identified in Table 1. The dotted curve shows that after controlling for aid, the hill disappears.

\section{From Aid to Growth}

The results in Table 3 explain the short-run association between democratization and increased rates of economic growth; this association is channeled by the immediate and substantial aid influx. The table does not, however, fully complete the causal chain. After all, 'foreign aid is not produced inside a country's borders, [and] should not show up in GDP in and of itself'. ${ }^{39}$ Yet 'if a reasonable fraction is spent inside the country, it should eventually appear in the national accounts'. ${ }^{40}$ This is an aggregate demand effect. When

38 Cf. Krieckhaus 2004.

39 Werker, Ahmed, and Cohen 2009, 226.

40 Ibid. 


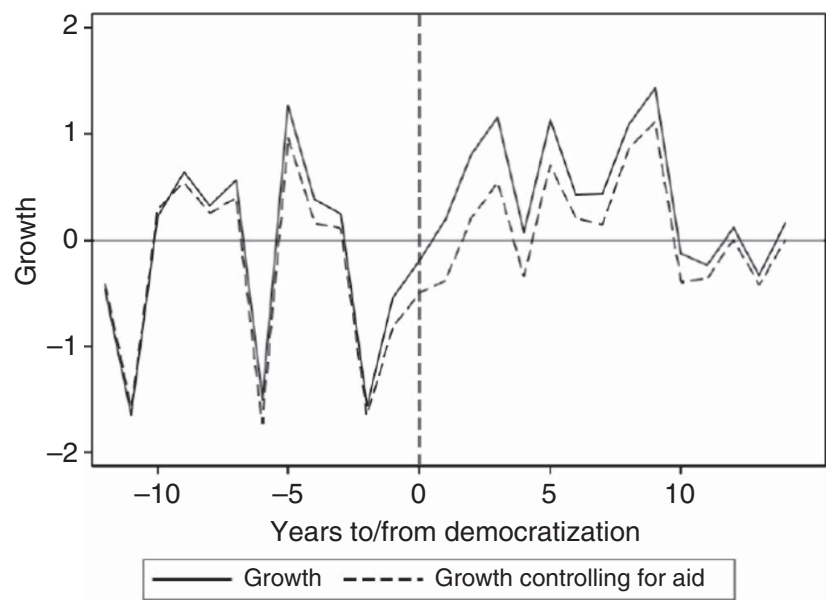

Fig. 2. How aid affects the democratization-growth nexus

Note: The figure shows the coefficients on dummies for each of the years surrounding democratization. The analysis includes country and year fixed effects. The solid curve shows growth around the time of democratization; the dashed curve shows growth after the effect of aid has been removed.

Sources: Marshall and Jaggers 2011, World Bank 2012.

spent, the inflow of funds from another country will cause the aggregate demand curve to shift outwards. If prices are less than infinitely elastic, this leads to a transitory output expansion in the short run. The fact that theoretically it must be a short-run effect is consistent with the findings above. The growth that follows democratization is transitory and decreases after about ten years. ${ }^{41}$

An aggregate demand effect is not only theoretically consistent with the findings, it is also consistent with the few empirical studies that trace the impact of aid through the national accounts. Werker et al. use variation in oil prices as a plausible source of exogenous variation in aid donations from OPEC countries to Muslim countries to examine how aid trickles through the economy. They find a substantive and significant effect on household consumption expenditure across different specifications. While the identification strategy alleviates doubt about the internal validity of these results, one might question the external validity (generalizability); their sample is a particular one. However, Chatterjee et al. find identical results ('aid is associated with a strong positive increase in household consumption') using a broader sample and more conventional instrumentation strategies. ${ }^{42}$

Therefore my argument is not that the institutional characteristics of democratization somehow improve the effectiveness of aid, an argument related to that of Burnside and

41 The long-run association between aid and growth is notoriously difficult to disentangle (see, for example, Arndt, Jones, and Tarp 2010; and Rajan and Subramanian 2008 for two divergent conclusions from identical data). However, the short-run association between aid and growth seems uncontroversial in the literature (see, for example, the meta-regression evidence in Doucouliagos and Paldam, 2011; Clemens et al. 2012; and Rajan and Subramanian 2008, 643).

42 Chatterjee, Guiliano, and Kaya 2012, 4-5. To fully describe the chain of causation, aid can affect private consumption through three potential channels: the government cuts taxes in response to the aid inflows, the aid is passed on as transfers or subsidies and/or the aid is distributed in the form of increased wages (Chatterjee, Guiliano, and Kaya 2012; Werker, Ahmed, and Cohen 2009). 
Dollar, who found that aid is growth enhancing conditional on good institutions and policies. ${ }^{43}$ I tested this by including an interaction between aid and democratization (or aid and the three democratization phases) in estimations that were otherwise similar to those in Table 3. In none of the models were the interaction terms close to statistical nor substantive significance (results are available on request).

At this point, the endogeneity of aid to growth must be addressed. Aid is not randomly allocated over recipient countries, but can be given to fast-growing countries to incentivize or reward performance. ${ }^{44}$ However, in the voluminous aid-growth literature, political motivations for giving aid are sometimes used as a source of exogenous variation in aid. ${ }^{45}$ Prima facie this logic bodes well for the results here, because the aid spike following democratization is likely to be politically motivated - suggesting that it is not given to reward countries that grow quickly in the first place.

Lastly, consider some alternative interpretations of the results in Table 3. The interpretation presented here is that aid is an intervening variable that mediates the association between democratization and growth. An alternative interpretation could be that countries democratize in expectation of aid inflows, such that aid explains both democratization and growth (the association between these variables would then be spurious). While the results showed that the pre-democratization indicator was rarely associated with aid (suggesting that democratization does not occur in response to aid), ${ }^{46}$ I should emphasize that this interpretation is not necessarily inconsistent with the overall claim made here. Namely, that the temporary growth hike that follows democratization is caused by aid rather than democratization itself. Another alternative interpretation could argue that a positive change in income explains both democratization and aid inflows. Yet in none of the models presented in Tables 1 and 3 was the pre-democratization indicator significantly associated with growth. This suggests that democratizations did not, in general, occur in response to improved economic performance. ${ }^{47}$

\section{HISTORICAL EVIDENCE AND ROBUSTNESS CHECKS}

Since aid in large measure is a post-1960 phenomenon, the association between growth and earlier waves of democratizations was not confounded by a simultaneous inflow of aid to young democracies. This observation is used to probe the plausibility of the results. If becoming a democracy in itself ignites a growth acceleration, we should expect pre- 1960 democratizations to also be growth enhancing. If, on the other hand, the growth effect

${ }^{43}$ Burnside and Dollar 2000. Dalgaard and Hansen 2001 and Easterly, Levine, and Roodman 2004 found that these results were generally not robust.

${ }^{44}$ Obviously, aid can also be given to slow-growing countries (to alleviate the consequences of poor performance), but since the findings suggest a positive effect of aid on growth, I focus on the potentiality of donors self-selecting into high-performing countries.

${ }^{45}$ For example, Rajan and Subramanian 2008, 648.

${ }^{46}$ Using both fixed effects and system GMM, Csordas and Ludwig $(2011,237)$ present evidence against the idea that foreign aid induces democratic transitions.

47 An anonymous referee suggested another alternative interpretation. The hill-shaped association between democratization and growth identified in Table 1 is consistent with the finding in Barro $(1996,14)$ that 'middle level democracy is most favorable to growth', because Phases 1 and 2 are middle-level democracy (average polity score is higher than non-democratizing countries and lower than Phase 3 countries). Barro speculates that democracy beyond an intermediate level might impair growth because of redistributive pressure. This might also be consistent with the argument presented here if foreign aid allows the recipient government to redistribute without resorting to distortionary taxation. 
TABLE 4 Historical Evidence and Sensitivity Checks

\begin{tabular}{|c|c|c|c|c|c|c|c|c|c|c|}
\hline & \multicolumn{10}{|c|}{ Dependent variable is GDP per capita growth } \\
\hline & \multicolumn{4}{|c|}{ Years $1820-1959$} & \multicolumn{6}{|c|}{$\begin{array}{l}\text { Alternative democracy index: } \\
\text { ACLP-indicator }\end{array}$} \\
\hline & (1) & (2) & (3) & (4) & (5) & (6) & (7) & (8) & (9) & $(10)$ \\
\hline Democratization & $\begin{array}{c}0.49 \\
(0.35)\end{array}$ & $\begin{array}{c}0.49 \\
(0.36)\end{array}$ & & $\begin{array}{c}0.47 \\
(0.34)\end{array}$ & $\begin{array}{l}\text { No aid } \\
0.74^{*} \\
(0.41)\end{array}$ & $\begin{array}{c}\text { Aid } \\
0.44 \\
(0.42)\end{array}$ & $\begin{array}{c}\text { No aid } \\
0.58^{*} \\
(0.35)\end{array}$ & $\begin{array}{c}\text { Aid } \\
0.34 \\
(0.37)\end{array}$ & No aid & Aid \\
\hline Democratization Phase 1 & & & $\begin{array}{c}0.19 \\
(0.42)\end{array}$ & & & & & & $\begin{array}{l}1.15^{*} \\
(0.63)\end{array}$ & $\begin{array}{c}0.94 \\
(0.62)\end{array}$ \\
\hline Democratization Phase 2 & & & $\begin{array}{c}-0.43 \\
(0.53)\end{array}$ & & & & & & $\begin{array}{l}1.07^{*} \\
(0.57)\end{array}$ & $\begin{array}{c}0.66 \\
(0.58)\end{array}$ \\
\hline Democratization Phase 3 & & & $\begin{array}{c}0.04 \\
(0.43)\end{array}$ & & & & & & $\begin{array}{c}-0.55 \\
(0.62)\end{array}$ & $\begin{array}{c}-0.98 \\
(0.66)\end{array}$ \\
\hline Pre-Democratization & & & & & $\begin{array}{c}-0.08 \\
(0.61)\end{array}$ & $\begin{array}{c}-0.04 \\
(0.63)\end{array}$ & $\begin{array}{c}-0.66 \\
(0.44)\end{array}$ & $\begin{array}{c}0.66 \\
(0.45)\end{array}$ & $\begin{array}{c}0.08 \\
(0.59)\end{array}$ & $\begin{array}{c}0.10 \\
(0.60)\end{array}$ \\
\hline Marshall aid dummy & & & & $\begin{array}{l}1.87 * * \\
(0.82)\end{array}$ & & & & & & \\
\hline Lag ln NAT & & & & & & $\begin{array}{l}0.85^{* * * *} \\
(0.26)\end{array}$ & & $\begin{array}{c}0.38 \\
(0.28)\end{array}$ & & $\begin{array}{l}0.79^{* * * *} \\
(0.26)\end{array}$ \\
\hline Other regime change & No & No & Yes & No & No & No & No & No & Yes & Yes \\
\hline Liberalization & No & No & No & No & No & No & No & No & No & No \\
\hline Economic controls & No & No & No & No & No & No & No & No & No & No \\
\hline Observations & 3,447 & 3,292 & 3,395 & 3,447 & 3,853 & 3,853 & 3,653 & 3,507 & 3,852 & 3,852 \\
\hline Countries & 78 & 78 & 78 & 78 & 132 & 132 & 129 & 129 & 132 & 132 \\
\hline $\mathrm{R}^{2}$ & 0.16 & 0.16 & 0.17 & 0.16 & 0.13 & 0.14 & 0.16 & 0.17 & 0.17 & 0.18 \\
\hline
\end{tabular}

Note: All models contain country and year fixed effects. Column 2 contains two lags of the dependent variable. Column 3 controls for autocratization and state failure. Robust standard errors clustered by country in parentheses. ${ }^{* *} \mathrm{p}<0.01,{ }^{* *} \mathrm{p}<0.05,{ }^{*} \mathrm{p}<0.1$. Sources: Cheibu,Gandhi and Vreeland (2009); Marshall and Jaggers (2011); Roodman (2008); and the World Bank (2012).

of democratization is confounded by the influx of aid, we should not expect democratizations before 1960 to be associated with increased rates of growth. ${ }^{48}$

Table 4 shows the coefficients from analyses of the growth effects of democratizations between 1820-1959. In Column 1, a single indicator variable takes the value 1 in all years after a country's score on polity 2 turns strictly positive. Column 2 allows for timepersistent growth rates. Column 3 shows the coefficients from an analysis that distinguishes between three phases. Column 4 is identical to Column 1, except that it includes a dummy for the years 1949-51 for the countries that were Marshall Aid recipients.

The results in Columns 1-4 in Table 4 are consistent with the conclusion reached earlier: prior to 1960, democratizations were not confounded by the influx of aid and were not associated with accelerated rates of economic growth. Similar to the coefficients in Table 3, here too the coefficients are positive but insignificant. Interestingly, the size of the coefficients from the earlier democratizations resembles the size of coefficients from later waves of democratization once the effect of aid is controlled for. Thus becoming a

\footnotetext{
${ }^{48}$ Democratizations in the nineteenth century likely differ from contemporary democratization in other respects than the absence of aid. These analyses do not therefore in any rigorous way constitute a test of the argument. I examine historical democratization merely to see if the economics of these are consistent with the argument.
} 
democracy has in the last five decades been associated with an average (but insignificant) growth effect of about 0.41 after controlling for aid (cf. Table 3, Column 1). Controlling for Marshall Aid years, the corresponding estimate for democratizations undertaken in the period $1820-1959$ is 0.47 , which is remarkably consistent.

The remaining six columns replace the Polity IV democracy index with the dichotmous ACLP indicator and replace the World Bank measure of aid with the log of the constant dollar amount of aid lagged one period from David Roodman's NAT dataset. ${ }^{49}$ With this data, the columns show the three core specifications, once without controlling for aid (Columns 5, 7 and 9) and once where aid is controlled for (Columns 6,8 and 10). Using the ACLP indicator, the democratization-growth association remains substantial and significant. Moreover, across model specifications, the coefficient on democratization is attenuated and loses significance when aid is controlled for, which is consistent with the overall conclusion of this study.

As a final robustness check, controls for political conflict were included. A body of work has shown that democratization may trigger both interstate and civil war. ${ }^{50}$ Since war affects the economy and might also affect donors' aid allocation, an association between democratization and war or political violence potentially confounds the estimates. To examine this, I used the Major Episodes of Political Violence dataset and re-ran Tables 1 and 3, controlling for political violence, civil war, the aftermath of civil war, interstate war and all of the above. ${ }^{51}$ In all cases, the inclusion of these controls leaves the argument intact: democratization is still positively associated with economic growth, and the association still disappears when aid is controlled for (results are available in the online appendix).

\section{CONCLUSION}

From earlier inquiries into the regime-development nexus, we inherited the somewhat paradoxical result that becoming a democracy is growth promoting but being one is not. Since previous research has found a significant association between democratization and growth even conditional on such plausible channels as economic liberalization, investment rates or trade flows, it was unclear what characteristic of young democracies stimulated growth and distinguished this set of countries from established democracies. The answer proposed here was foreign aid: receiving aid distinguishes democratizing countries from democratic countries and can also plausibly generate a transitory aggregate demand expansion that stimulates growth. This result resolved the paradox, since neither democracy nor democratization is in itself distinguished by higher rates of economic growth.

49 Democratization was operationalized using the ACLP indicator, as with Polity IV. It takes the value 1 in the year in which a country goes from autocracy to democracy. It stays at 1 if the country does not revert back to autocracy. Phases 1-3 are also defined as above. The specific coding rules (cf. note 21) and the estimation approach are also unchanged.

${ }^{50}$ See, for example, Cederman, Hug, and Krebs 2010; Mansfield and Snyder 2002.

51 More specifically, I did the following: (1) Added controls for civil war and international war (categorical variables running from 0-10) individually and separately, and experimented with different lags to allow for a few years of stability before the influx of aid began. (2) Coded a dummy variable to directly capture the aftermath of civil war. This dummy is coded as 1 in the first year in which the civil war variable turns 0 , given that it was 4 or more in the previous year (on the $0-10$ categorical variable, 3 is defined as 'serious political violence' and 4 is defined as 'serious warfare'). (3) Coded a dummy variable to capture political violence that does not qualify as either international war or civil war. This was defined to include all instances in the interval 1-3 on the international war variable or the civil war variable. None of these variables, individually or together, change the results presented here. 
The results proved robust to a set of different empirical specifications, to alternative democracy indices, to alternative measures of foreign aid, to a broad set of economic controls and to controls for political conflict. The historical implication of the findings that prior to 1960 and foreign aid as we know it, democratization should not bring growth - could also not be rejected.

The conclusion, that the economic effects of democratization cannot be understood from domestic factors alone, complements the emerging consensus on the importance of external factors and interstate linkages in explaining the onset of democratic regime change. External factors are important to understanding both the causes and consequences of democratization.

Methodologically, this study suggests caution when interpreting reduced-form associations between political institutions and economic outcomes. It is often unclear how a certain political arrangement affects the economy, and mediating variables can rarely be found. This leaves the field vulnerable to treating spurious associations as causal. One solution seems to be to push back and zoom in on the mediating variables where a clear causal narrative can be provided as to why a certain political institution has led to the observed consequences.

The results in this article also have implications for practitioners in the development community. A large empirical literature has established the importance of institutions for comparative economic development, ${ }^{52}$ and the democratization-growth literature clearly reflects this institutionalist turn. The academic interest in institutions has been mirrored in the community of aid organizations, as codified in the so-called Augmented Washington Consensus, ${ }^{53}$ which brought institutional reform and good governance to the forefront of the development agenda. This makes sense: if institutions are instrumental in achieving growth and alleviating poverty, why not tie aid allocations to measures of institutional performance?

The conclusions inform development policy by pointing to an interesting circularity: foreign assistance is allocated to countries that undertake institutional reform or perform well on institutional indices on the presumption that institutional reform will spur economic growth. In the case of democratic institutional reform, however, it is not the political reforms themselves that enhance growth - it is the inflow of foreign assistance.

Thus in the short run, there seems to be a confounding of the effect of what development organizations preach (institutional reform) and the effect of the 'reward' (aid) given to countries that comply. While this has only been documented for the case of democratic reform, it could plausibly also relate to other types of institutional reform.

\section{REFERENCES}

Acemoglu, Daron, Simon Johnson, and James A. Robinson. 2001. The Colonial Origins of Comparative Development: An Empirical Investigation. The American Economic Review 91 (5):1369-401.

Arndt, Channing, Sam Jones, and Finn Tarp. 2010. Aid, Growth, and Development: Have we Come Full Circle? Journal of Globalization and Development 1 (2):1-27.

Barro, Robert. 1996. Democracy and Growth. Journal of Economic Growth 1 (1):1-27.

Bertrand, Marianne, Esther Duflo, and Sendhil Mullainathan. 2004. How Much Should We Trust Differences-In-Differences Estimates? The Quarterly Journal of Economics 119 (1):249-75.

\footnotetext{
52 For example, Acemoglu, Johnson, and Robinson 2001.

53 Rodrik 2006.
} 
Burnside, Craig, and David Dollar. 2000. Aid, Policies, and Growth. American Economic Review 90 (4):847-68.

Carothers, Thomas. 1999. Aiding Democracy Abroad: The Learning Curve. Washington, DC: Carnegie Endowment for International Peace.

Cederman, Lars-Erik, Simon Hug, and Lutz F. Krebs. 2010. Democratization and Civil War: Empirical Evidence. Journal of Peace Research 47 (4):377-94.

Chatterjee, Santanu, Paola Guiliano, and Ilker Kaya. 2012. Where has all the Money Gone? Foreign Aid and the Composition of Government Spending. B. E. Journal of Macroeconomics $12(1): 1-34$.

Cheibub, Jose Antonio, Jennifer Gandhi, and James Raymond Vreeland. 2009. Democracy and Dictatorship Revisited. Public Choice 143 (1-2):67-101.

Clemens, Michael, Steven Radelet, Rikhil Bhavnani, and Samuel Bazzi. 2012. Counting Chickens When they Hatch: Timing and the Effects of Aid on Growth. The Economic Journal 122 (561):590-617.

Cornell, Agnes. 2012. Does Regime Type Matter for the Impact of Democracy Aid on Democracy? Democratization 20 (4):642-67.

Csordas, Stefan, and Markus Ludwig. 2011. An Imperical Investigation of the Determinants of Democracy. Economics Letters 110:235-7.

Dahl, Robert. 1971. Polyarchy: Participation and Opposition. New Haven, CT: Yale University Press.

Dahrendorf, Ralf. 1990. Transitions: Politics, Economics, and Liberty. The Washington Quarterly $13(3): 133-42$.

Dalgaard, Carl-Johan, and Henrik Hansen. 2001. On Aid, Growth, and Good Policies. Journal of Development Studies 37 (6):17-41.

Dalgaard, Carl-Johan, Henrik Hansen, and Finn Tarp. 2004. On the Empirics on Foreign Aid and Growth. The Economic Journal 114:191-216.

Dellepiane-Avellaneda, Sebastian. 2010. Good Governance, Institutions and Development: Beyond the Conventional Wisdom. British Journal of Political Science 40 (1):195-224.

Doucouliagos, Hristos, and Martin Paldam. 2011. The Ineffectiveness of Development Aid on Growth: An Update. European Journal of Political Economy 27:339-404.

Drury, A. Cooper, Richard S. Olson, and Douglas A. Van Belle. 2005. The Politics of Humanitarian Aid: U. S. Foreign Disaster Assistance, 1964-1995. The Journal of Politics 67 (2):454-73.

Easterly, William, Ross Levine, and David Roodman. 2004. Aid, Policies, and Growth. The American Economic Review 94 (3):774-80.

Elkink, Johan A. 2011. The International Diffusion of Democracy. Comparative Political Studies 44 (12):1651-74.

Giavazzi, Francesco, and Guido Tabellini. 2005. Economic and Political Liberalizations. Journal of Monetary Economics 52 (7):1297-330.

Gleditsch, Kritstian Skrede, and Lars-Erik Cederman. 2004. Conquest and Regime Change: An Evolutionary Model of the Spread of Democracy and Peace. International Studies Quarterly 48 (3):603-29.

Gleditsch, Kritstian Skrede, and Michael D. Ward. 2006. Diffusion and the International Context of Democratization. International Organization 60 (4):911-33.

Hansen, Henrik, and Finn Tarp. 2000. Aid Effectiveness Disputed. Journal of International Development 12 (3):375-98.

Helpman, Elhanan. 2004. The Mystery of Economic Growth. Cambridge, MA: Harvard University Press.

Huntington, Samuel. 1991. The Third Wave: Democratization in the Late Twentieth Century. Norman: University of Oklahoma Press.

King, Gary, and Margaret Roberts. 2012. How Robust Standard Errors Expose Methodological Errors They Do Not Fix. Working Paper. http://j.mp/lnK5jU 
Knack, Stephen. 2004. Does Foreign Aid Promote Democracy? International Studies Quarterly 48 (1):251-66.

Krieckhaus, Jonathan. 2004. The Regime Debate Revisited: A Sensitivity Analysis of Democracy's Economic Effect. British Journal of Political Science 34 (4):635-55.

—. 2006. Democracy and Economic Growth: How Regional Context Influences Regime Effects. British Journal of Political Science 36 (2):317-40.

Lijphart, Arend. 1999. Patterns of Democracy: Government Forms and Performance in Thirty-Six Countries. New Haven: Yale University Press.

Maddison, Angus. 2010. Statistics on World Population, GDP, and Per Capita GDP. 1-2008. Available at www.ggdc.net/maddison/Maddison.htm

Mansfield, Edward D., and Jack Snyder. 2002. Democratic Transitions, Institutional Strength, and War. International Organization 56 (2):297-337.

Marshall, Monty G., and Keith. Jaggers 2011. Polity IV Project: Political Regime Characteristics and Transitions, 1800-2010. Available at http://www.systemicpeace.org/polity/polity4.htm

Munck, Gerado L., and Jay Verkuilen. 2002. Conceptualizing and Measuring Democracy: Evaluating Alternative Indices. Comparative Political Studies 35 (1):5-34.

Papaioannou, Elias, and Gregorios Siourounis. 2008. Democratisation and Growth. Economic Journal 118 (532):1520-51.

Persson, Torsten. 2005. Forms of Democracy, Policy and Economic Development. Discussion Paper No. 4938. London: Centre for Economic Policy Research.

Persson, Torsten, and Guido Tabellini. 2006. Democracy and Development: The Devil in the Details. The American Economic Review 96 (2):319-24.

Persson, Torsten., and Guido. Tabellini 2007. The Growth Effect of Democracy: Is it Heterogeneous and How Can it be Estimated? NBER Working Papers No. 13150.

Przeworski, Adam, and Fernando P. Limongi. 1993. Political Regimes and Economic Growth. The Journal of Economic Perspectives 7 (3):51-69.

Przeworski, Adam, Michael M. Alvarez, José Antonio. Cheibub, and Fernando Limongi. 2000. Democracy and Development: Political Institutions and Well-Being in the World, 1950-1990. Cambridge: Cambridge University Press.

Rajan, Raghuram G., and Arvind Subramanian. 2008. Aid and Growth: What Does the Cross-Country Evidence Really Show? The Review of Economics and Statistics 90 (4):643-65.

Rodrik, Dani. 2006. Goodbye Washington Consensus, Hello Washington Confusion? A Review of the World Bank's Economic Growth in the 1990s. Learning from a Decade of Reform. Journal of Economic Literature XLIV:973-87.

Rodrik, Dani, and Romain Wacziarg. 2005. Do Democratic Transitions Produce Bad Economic Outcomes? American Economic Review 95 (2):50-5.

Roodman, David. 2008. Net Aid Transfers Data Set (1960-2007). Available at http://cgdev.org/ content/publications/detail/5492

Sirowy, Larry, and Alex Inkeles. 1990. The Effects of Democracy on Economic Growth and Inequality: A Review. Studies in Comparative International Development 25 (1):126-57.

Starr, Harvey. 1991. Democratic Dominoes: Diffusion Approaches to the Spread of Democracy in the International System. The Journal of Conflict Resolution 35 (2):356-81.

Vanhanen, Tatu. 2000. A New Dataset for Measuring Democracy, 1810-1998. Journal of Peace Research 37 (2):251-65.

Werker, Eric, Faisal Z. Ahmed, and Charles Cohen. 2009. How is Foreign Aid Spent? Evidence from a Natural Experiment. American Economic Journal: Macroeconomics 1 (2): 225-44.

Wright, Joseph, and Matthew Winters. 2010. The Politics of Effective Foreign Aid. The Annual Review of Political Science 13:61-80.

World Bank. 2012. World Development Indicators, CD-ROM. Washington, DC: World Bank.

Zakaria, Fareed. 2003. The Future of Freedom: Illiberal Democracy at Home and Abroad. New York: W.W. Norton and Company, Inc. 